\title{
Pedigree Analysis of Factor XI Deficiency in Japanese Black Cattle
}

\author{
Yasunori OHBA $^{1)}$, Masaki TAKASU ${ }^{2)}$, Naohito NISHII ${ }^{2)}$, Eri TAKEDA ${ }^{1)}$, Sadatoshi MAEDA ${ }^{1)}$, Tetsuo KUNIEDA ${ }^{3)}$ and \\ Hitoshi KITAGAWA ${ }^{1)}$ \\ ${ }^{1)}$ Department of Veterinary Medicine, Faculty of Applied Biological Sciences and ${ }^{2)}$ Department of Clinical Veterinary Medicine, United \\ Graduate School of Veterinary Sciences, Gifu University, 1-1 Yanagido, Gifu 501-1193 and ${ }^{3)}$ Graduate School of Natural Science and \\ Technology, Okayama University, Tsushima-naka, Okayama 770-8530, Japan
}

(Received 22 August 2007/Accepted 6 November 2007)

ABSTRACT. Using a DNA-based diagnostic test for factor XI deficiency in Japanese black cattle, we surveyed 123 cattle (42 sires and 81 dams) in Gifu and Hyogo prefectures, and calculated gene frequencies. In sires, we drew up the pedigree network of the cattle with the factor XI deficiency. Results showed that the mutated allele of factor XI deficiency was retroactive in at least 6 or more generations of sires. Frequencies of the mutant gene were higher at $26.4 \%$ in total, and at $33.3 \%$ in sires. All 7 cattle with the homozygote of mutated allele were clinically normal, and showed no bleeding episodes. The mutated allele of factor XI deficiency might be widespread among Japanese black cattle.

KEY WORDS: factor XI deficiency, gene frequency, Japanese black cattle.

J. Vet. Med. Sci. 70(3): 297-299, 2008

Factor XI deficiency has been found in Holstein and Japanese black cattle. The disease is a hereditary coagulation disorder with an autosomal recessive mode of inheritance. Factor XI (plasma thromboplastin antecedent) is the zymogen of a plasma serine protease, which is involved in the early stage of blood coagulation. The active form of factor XI (factor XIa) promotes blood coagulation by activating factor IX [3]. Factor XI deficiency has also been reported in Holstein cattle in Britain, U.S.A. and Canada $[1,5,6]$, and a responsible $F 11$ gene mutation in the factor XI deficiency of Holsteins [9]. The mutation was an insertion of a 76-bp segment in exon 12 of the $F 11$ gene, which introduced a premature termination codon at the $\mathrm{C}$-terminal region of the protein. Likewise, Kunieda and others [7] recently reported a causative mutation in Japanese black cattle and the mutation was an insertion of 15 nucleotides in exon 9 of the F11 gene. Thus, the causative mutation of factor XI deficiency has been different in Holstein and Japanese black cattle.

Using a DNA-based diagnostic test, Marron and others [9] reported that the frequencies of the mutant gene have been $1.2 \%$ in a contemporary population of Holstein sires in U.S.A. In Japan, however, there has been no report on its frequency in generally bred Japanese black cattle, though there was one on stunted Japanese black cattle [11]. We investigated the frequencies of the mutant gene in sires and dams of Japanese black cattle.

Blood and sperm samples of 123 Japanese black cattle (42 sires and 81 dams) in Gifu and Hyogo prefectures were collected at random. Genomic DNAs were isolated from the blood cells of the cattle by phenol-chloroform extraction. DNA samples of Japanese black cattle were used in the present study. PCR primers detecting the normal and

\footnotetext{
* Correspondence to: Kitagawa, H., Department of Veterinary Medicine, Faculty of Applied Biological Sciences, Gifu University, 1-1 Yanagido, Gifu 501-1193, Japan.

e-mail: hkitagaw@gifu-u.ac.jp
}

mutant genes of the $F 11$ gene in cattle have been reported [7]. A 95-bp region flanking the insertion was amplified by PCR using a pair of primers 5'-TCACATCTCAATATGTGCTTCTGC-3' and 5'-TCTACGATGTCCAGTTCTTCTCC-3'. The PCR products were electrophoresed through 3\% agarose gel in TBE buffer and visualized with ethidium bromide staining. PCR amplification was carried out for 40 cycles consisting of denaturation at $94^{\circ} \mathrm{C}$ for 30 sec, annealing at $60^{\circ} \mathrm{C}$ for $30 \mathrm{sec}$, and extension at $72^{\circ} \mathrm{C}$ for $30 \mathrm{sec}$. The $50-\mu l$ reaction mixture contained $20 \mathrm{ng}$ genomic DNA, $0.4 \mu \mathrm{g}$ of each primer, $2.5 \mathrm{U}$ of Taq polymerase, $200 \mathrm{mM}$ of dNTPs, and Taq buffer containing 1.5 $\mathrm{mM} \mathrm{Mg}^{2+}$.

Figure 1 shows the pedigree network of sires with a factor XI deficiency. Sires with the heterozygote covered 6 generations. Especially, sires with the heterozygote included those with excellent meat quality, such as YMD, YTD and YF. Table 1 shows results of analyses using a DNA-based diagnostic test. Three of 42 sires $(7.1 \%)$ had the homozygote of mutated allele, along with 4 of 81 dams (4.9\%). All 7 cattle with the homozygote of mutated allele were normal in clinical symptoms, and showed no bleeding episodes. All 4 dams with the homozygote of mutated allele showed no degeneration of fecundity. Moreover, 22 of 42 sires $(52.4 \%)$ and 29 of 81 dams $(35.8 \%)$ had the heterozygote. Table 2 shows results of normal and mutant gene frequencies. Frequencies of the mutant gene were very high at $26.4 \%$ in total, as well as at $33.3 \%$ and $22.8 \%$, in sires and dams, respectively. In pedigree analysis, all dams with mutated allele had relationship to sires with mutated allele.

In this study, 7 cattle detected with the homozygote of mutated allele had no clinical symptoms. Watanabe et al. [11] reported no clinical bleeding tendency in cattle with factor XI deficiency. However, several groups of investigators found that animals affected by factor XI deficiency in Canadian Holstein cattle showed a lower rate of fetal and 


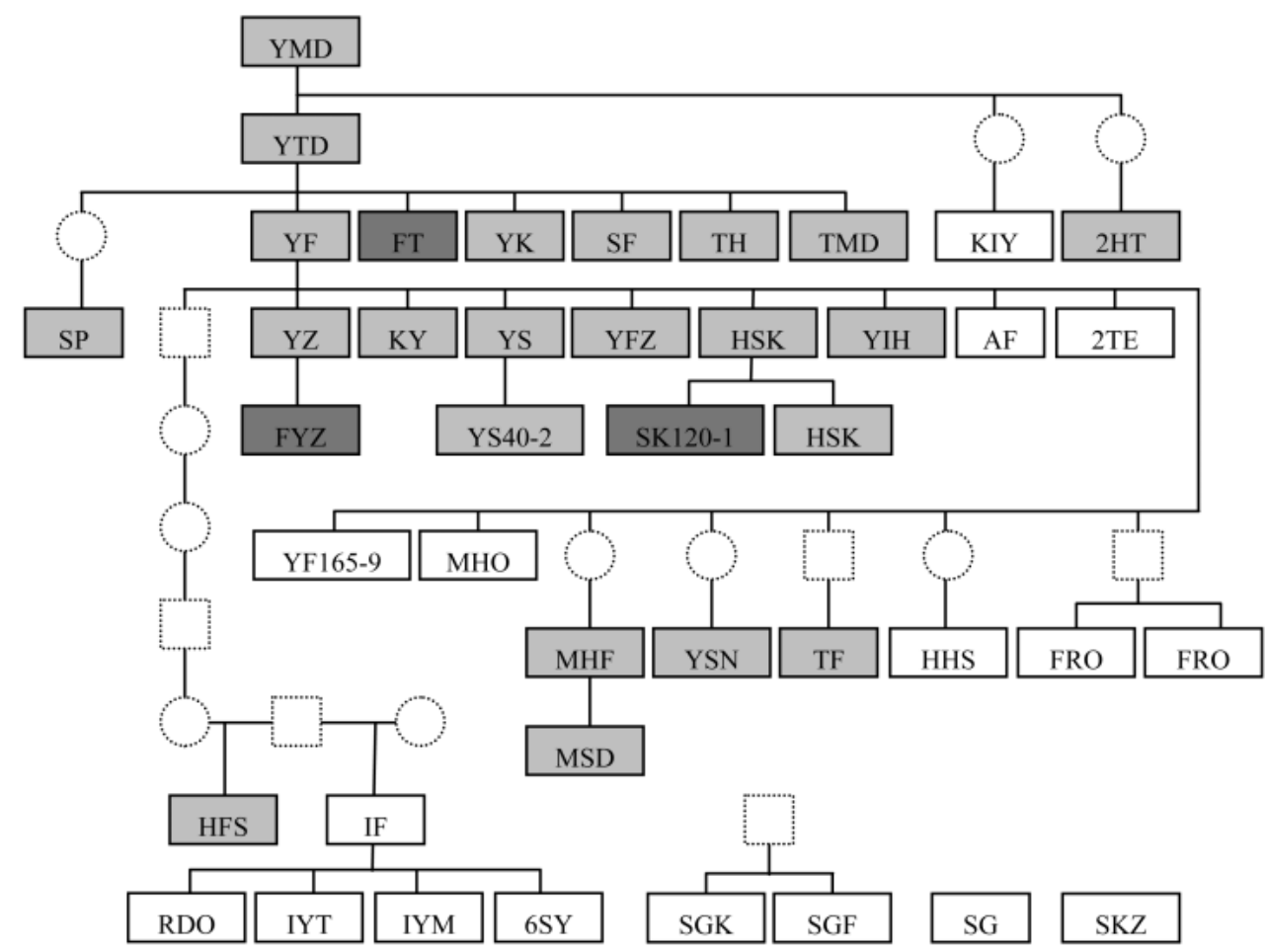

Fig. 1. Pedigree network of sires with factor XI deficiency. $\square$ : male, $\bigcirc$ : female, $\square$ : homozygote of mutated allele, $\square$ : heterozygote, $\square$ : homozygote of normal allele, $\square$ and : unknown. Rectangles enclosing capital letters indicate 42 sires examined.

Table 1. Results of analyses using a DNA-based diagnostic test

\begin{tabular}{lccc}
\hline & \multicolumn{3}{c}{ Number of cattle } \\
\cline { 2 - 4 } Cattle & $\begin{array}{c}\text { Homozygote } \\
\text { of normal allele }\end{array}$ & Heterozygote & $\begin{array}{c}\text { Homozygote } \\
\text { of mutated allele }\end{array}$ \\
\hline Sires & 17 & 22 & 3 \\
Dams & 48 & 29 & 4 \\
\hline Total & 65 & 51 & 7 \\
\hline
\end{tabular}

Table 2. Gene frequencies (\%)

\begin{tabular}{lcc}
\hline Cattle & Normal & Mutant \\
\hline Sires & 66.7 & 33.3 \\
Dams & 77.2 & 22.8 \\
\hline Total & 73.6 & 26.4 \\
\hline
\end{tabular}

calf survival, higher susceptibility to infectious diseases, and higher frequencies of repeat breeders $[2,4,8]$. These differences in clinical symptoms might be due to the differences in causative mutation of the $F 11$ gene, in the characteristic of kind or in the breeding environment, between the Holstein and Japanese black cattle. We reported previously a Japanese black calf with factor XI deficiency showing hemostatic deficiency, growth retardation and hip dysplasia [10]. In this calf, the bleeding episode occurred only once, and no bleeding tendency was observed before and after. In Japanese black cattle, it is possible that factor XI deficiency may not show any symptoms by itself, but that it could show hemorrhaging symptoms in association with other factors. In any case, more Japanese black cattle with the homozygote of mutant allele must be examined in order to demonstrate whether cattle affected with factor XI deficiency have clinical symptoms.

The present study indicated that the mutated allele of factor XI deficiency is widespread in the examined area. Sires with very excellent meat quality, such as YMD, YTD, YF (Fig. 1) and many of their descendants have been used as sires and dams throughout Japan. Moreover, cattle with the homozygote of mutated allele or the heterozygote are overlooked and not culled, since these cattle do not show any clinical symptoms. For these reasons, we consider that the mutated allele of factor XI deficiency might be widespread among Japanese black cattle.

ACKNOWLEDGEMENTS. The authors wish to gratefully thank Gifu and Hyogo prefectures, which contributed to this study by collecting blood and sperm samples of cattle and data for the pedigree analysis.

\section{REFERENCES}

1. Brush, P. J., Anderson, P. H. and Gunning, R. F. 1987. Vet. 
Rec. 121: 14-17.

2. Coomber, B. L., Galligan, C. L. and Gentry, P. A. 1997. Vet. Immunol. Immunopathol. 58: 121-131.

3. Davie, E. W., Fujikawa, K. and Kisiel, W. 1991. Biochemistry 30: 10363-10370.

4. Gentry, P. A. and Ross, M. L. 1993. Can. J. Vet. Res. 58: 242247.

5. Gentry, P. A., Crane, S. and Lotz, F. 1975. Can. Vet. J. 16: 160-163.

6. Kociba, G. J., Ratnoff, O. D., Loeb, W. F., Wall, R. L. and Heider, L. E. 1969. J. Lab. Clin. Med. 74: 37-41.

7. Kunieda, M., Tsuji, T., Abbasi, A. R., Khalaj, M., Ikeda, M.,
Miyadera, K., Ogawa, H. and Kunieda, T. 2005. Mamm. Genome 16: 383-389.

8. Liptrap, R. M., Gentry, P. A., Ross, M. L. and Cummings, E. 1995. Vet. Res. Commun. 19: 463-471.

9. Marron, B. M., Robinson, J. L., Gentry, P. A. and Beever, J. E. 2004. Anim. Genet. 35: 454-456.

10. Takasu, M., Takeda, E., Nishii, N., Ohba, Y., Maeda, S., Miyazawa, K., Ogawa H. and Kitagawa, H. 2005. J. Jpn. Vet. Med. Assoc. 58: 820-822. (in Japanease).

11. Watanabe, D., Hirano, T., Sugimoto, Y., Ogata, Y., Abe, S., Ando, T., Ohtsuka, H., Kunieda, T. and Kawamura, S. 2006. J. Vet. Med. Sci. 68: 1251-1255. 